\title{
MENINGKATKAN MINAT BELAJAR SISWA DENGAN MENGGUNAKAN MODEL LACAK KATA DI KELAS X MIPA 2 SMA NEGERI 7 PADANG
}

\section{IMPROVING STUDENT'S LEARNING INTEREST BY USING WORD TRACKING MODEL IN CLASS X MIPA 2 SMA NEGERI 7 PADANG}

\author{
Daswita \\ SMA Negeri 7 Padang \\ daswitady@gmail.com
}

\begin{abstract}
ABSTRAK : Penelitian tindakan ini dilakukan untuk mengetahui seberapa efektif penggunaan model lacak kata dalam meningkatkan hasil belajar siswa di SMA N 7 Padang. Penelitian ini merupakan penelitian tindakan kelas yang bertujuan untuk memecahkan masalah pembelajaran di sekolah. Subjek penelitian adalah siswa kelas X IPA 2 SMA N 7 Padang pada semester genap tahun pelajaran 2019/2020. Ada tiga siklus dalam penelitian ini, Setiap siklus dilakukan dalam empat tahapan kegiatan, yakni : perencanaan, pelaksanaan, pengamatan dan pemantulan. Analisis tiap siklus didasarkan pada hasil tes untuk melihat kemampuan kognitif dan hasil pengamatan untuk mengetahui sikap dan minat siswa. Data dianalisis dengan menggunakan teknik analisis deskriptif komparatif. Hasil penelitian menunjukkan bahwa penggunaan model lacak kata dapat meningkatkan hasil belajar dan minat siswa. Hal ini terlihat dari kecendrungan peningkatan hasil belajar dan minat siswa setiap siklus.
\end{abstract}

Kata kunci : minat belajat, lacak kata, mata pelajaran Bahasa Indonesia

ABSTRACT : This action research was conducted to determine how effective the use of the word tracing model was in improving student learning outcomes at SMA N 7 Padang. This research is a classroom action research that aims to solve learning problems in schools. The research subjects were students of class X MIPA 2 SMA $N 7$ Padang in the even semester of the 2019/2020 school year. There are three cycles in this research. Each cycle is carried out in four stages of activity, namely: planning, implementing, observing and reflecting. The analysis of each cycle is based on test results to see cognitive abilities and observations to determine student attitudes and interests. Data were analyzed using comparative descriptive analysis techniques. The results showed that the use of word tracing models could improve student learning outcomes and interest. This can be seen from the tendency of increasing learning outcomes and student interest in each cycle.

Keywords: interest in learning, word tracing, Indonesian subjects

\section{A. PENDAHULUAN}

Bahasa Indonesia merupakan salah satu mata pelajaran di Sekolah Menengah Atas (SMA). Berdasarkan kurikulum 2013, Mata Pelajaran Bahasa Indonesia merupakan penghela bagi mata pelajaran lain. Di samping itu, Mata Pelajaran Bahasa Indonesia berbasis teks yang dititikberatkan pada empat keterampilan berbahasa yakni membaca, menulis, menyimak dan mendengar. Pemahaman terhadap esensi mata pelajaran tersebut, menuntut siswa agar memiliki pengetahuan yang dalam tentang hakikat bahasa sebagai alat 
komunikasi. Baik lisan maupun tulis. Pemahaman tersebut dapat dilakukan melalui pemberian pengetahuan tentang konsep dasar kebahasaan terutama dalam hal mengkaji peranan bahasa dalam membentuk pola pikir dan perilaku manusia.

Pentingnya peranan bahasa dalam membentuk perilaku berbahasa siswa, menuntut perlunya penanaman konsep yang jelas tentang esensi materi pelajaran yang akan diberikan kepada siswa. Pembelajaran bahasa yang disajikan pada siswa hendaknya dapat memberikan pengalaman dan kesempatan kepada siswa untuk mengkaji, menganalisis, serta menginterpretasi tentang teori dan praktik kebahasaan sehingga siswa dapat berpikir secara kritis, logis dan sistematis dalam menjalin komunikasi secara baik dan benar. Dengan demikian, secara akademis siswa dituntut memiliki pengetahuan dan keterampilan untuk mengenal dan mengembangkan cara berpikir dan bersikap dalam berbahasa dengan cara melatih siswa untuk menerapkan konsep-konsep berbahasa serta aplikasinya dalam pembelajaran.

Faktanya di lapangan minat belajar siswa dalam menerima materi pelajaran kurang, siswa enggan untuk membaca materi pelajaran, siswa kurang respon saat diberi pertanyaan, siswa tidak mencatat bagian penting materi yang disajikan guru, dan kurang mau bertanya. Untuk itu penulis mencoba mencari akar permasalahannya berdasarkan pengalaman mengajarkan mata pelajaran bahasa Indonesia,di antaranya diperoleh gambaran : (1) minat siswa yang kurang,perlu diberi latihan yang terarah, berencana dan berkesinambungan. Animo siswa yang rendah untuk membaca dapat ditingkatkan dengan pemberian motivasi (3) siswa yang kurang bersemangat untuk mengerjakan tugas perlu diberi rangsangan agar siswa terdorong untuk mengerjakan tugas sehingga prestasi siswa meningkat.

Permasalahan yang serius ini perlu segera diatasi serta dicarikan jalan keluarnya. Peneliti mencarikan solusinya dengan menggunakan model Lacak Kata. Hal ini disebabkan karena model ini menampilkan perubahan (change) dan memunculkan pembaruan (inovation) dalam belajar di kelas. Sebagai akibatnya, minat siswa tumbuh dan berkembang.

Menurut Sujanto (2012) minat mempengaruhi hasil belajar. Tidak usah diharapkan kalau orang tidak berminat untuk mempelajari sesuatu maka dia akan berhasil dengan baik dalam mempelajari hal tersebut. Sebaliknya, kalau orang mempelajari sesuatu dengan penuh minat, maka dapat diharapkan bahwa hasilnya akan lebih baik.

Menurut Semiawan (2000) minat adalah suatu keadaan mental yang menghasilkan respon terarah kepada suatu situasi atau objek tertentu yang menyenangkan dan memberikan kepuasan kepadanya. Seseorang akan berminat pada suatu objek atau kegiatan bila objek atau kegiatan itu menimbulkan perasaan senang pada dirinya. Perasan pada objek merupakan kunci untuk melihat berminat tidaknya seseorang pada objek atau kegiatan tersebut. .

Dari pendapat di atas dapat disimpulkan bahwa minat belajar merupakan faktor penting dalam menunjang keberhasilan seseorang untuk melakukan aktivitas atau kegiatan dengan penuh kesungguhan dan bersemangat dalam belajar.

Lacak kata atau disebut juga dengan TTS sering ditemukan di koran atau majalah.

Menurut Guntur Tarigan ( 2011) lacak kata merupakan permainan kata yang amat popular. Lacak kata dapat memperkaya kosa kata para siswa. Lacak kata mengasikkan dalam belajar, bermain sambil memperkaya kosakata.

Silberman (2006) mengatakan lacak kata adalah permainan kata yang mengundang minat belajar dan partisipasi siswa. Lacak kata bisa diisi secara perseorangan atau kelompok. 
Sedangkan, menurut Trisupeni (1994) lacak kata merupakan salah satu model alternatif yang dapat digunakan untuk membangkitkan minat siswa, sehingga siswa akan lebih bergairah dalam mengerjakan tugas-tugas yang diberikan dan hasil belajar dapat ditingkatkan.

Berdasarkan pendapat para ahli di atas dapat disimpulkan bahwa lacak kata merupakan permainan kata yang dapat memperkaya kosa kata seseorang dan dapat dijadikan sebagai salah satu model alternatif untuk membangkitkan minat siswa.

Bertitik tolak dari permasalahan di atas, peneliti menganggap pentingnya sebuah penelitian untuk melihat dan mengungkapkan secara empiris keefektifan penggunaan model Lacak Kata untuk meningkatkan minat belajar siswa. Hal ini didasari oleh suatu realita bahwa pembelajaran bahasa Indonesia masih biasa-biasa saja, sehingga perlu suatu terobasan ke arah yang lebih inovatif dan menyenangkan. Guru dapat berkreasi dan berinovasi secara efisien dan efektif dalam menggunakan model ini. Model ini dapat mengatasi permasalahan kurangnya minatnya siswa dalam belajar, dengan sasaran hasil belajar siswa mengalami peningkatan dari sebelumnya. Dalam proses belajar mengajar siswa mengisi kotak yang telah disediakan dengan kata yang tepat sesuai dengan pertanyaan atau pernyataan yang disediakan guru.

\section{B. METODOLOGI PENELITIAN}

Rancangan penelitian tindakan kelas yang peneliti gunakan adalah model Lewin. Model Lewin dalam Hopkins (1993) terdiri dari empat unsur, antara lain: 1) Perencanaan (Planning), 2) Tindakan (Acting), 3) Pengamatan (Observating), dan 4) Pemantulan (Reflecting). Hubungan keempat unsur tersebut saling berkaitan dalam satu siklus. Di samping itu rancangan penelitian ini mempedomani rancangan Eliot (1983) dan Kemmis (1982). Mereka mengatakan bahwa penelitian tindakan kelas adalah penelitian yang dirancang untuk pemecahan masalah utama dalam pembelajaran dengan meningkatkan proses dan hasil pembelajaran.

Objek tindakan adalah menggunakan model pembelajaran lacak kata sebagai tindakan untuk memperbaiki pembelajaran. Dengan menggunakan model ini akan menimbulkan minat, daya tarik siswa,dan membangkitkan animo siswa untuk belajar yang selama ini mereka kurang bergairah untuk belajar menjadi lebih bersemangat.

Penelitian ini dilaksanakan di SMA Negeri7 Padang tahun pelajaran 2019/2020 semester genap. Subjek Penelitian adalah siswa kelas X.MIPA.2 yang berjumlah 36 orang.

Sumber data berasal dari dua kelompok. Pertama sumber data dari siswa sebagai subjek penelitian. Kedua sumber data dari guru pengamat sekaligus guru peneliti. Sumber data dari siswa pada umumnya berupa angka-angka yang diperoleh dari nilai tes uji kompetensi siklus I, siklus II dan siklus III dengan tidak mengganggu jadwal pengajaran dan kurikulum yang berlaku. Sedangkan sumber data dari guru pengamat dan guru peneliti pada umumnya berbentuk deskripsi atau paparan hasil pengamatan selama proses belajar mengajar berlangsung.

\section{Teknik Pengumpulan Data}

Teknik pengumpulan data pada penelitian ini adalah melalui pemberian : a. Tes

Tes atau uji kompetensi diberikan setelah siswa mendapat tindakan sesuai dengan materi yang diberikan dan kurikulum yang berlaku yaitu kurikulum 2013 untuk mata pelajaran Bahasa Indonesia. Dalam hal ini, tes yang diberikan telah dipersiapkan terlebih 
dahulu pada tahap perencanaan. Tes atau uji kompetensi diberikan setiap akhir siklus. Hasil tes dibandingkan setiap siklus.

b. Pengamatan

Pengamatan dilakukan oleh peneliti ketika sedang melakukan tindakan. Aspek pengamatan dilakukan sesuai dengan bentuk - bentuk tindakan yang dilakukan peneliti baik terhadap siswa maupun terhadap peneliti itu sendiri.

\section{Teknik Analisis Data}

Analisis data dalam penelitian tindakan kelas ini dilakukan melalui analisis deskriptif komparatif. Analisis deskriptif komparatif adalah analisis yang menguraikan kejadian atau rekaman apa yang telah dilakukan dalam penelitian tindakan kelas, kemudian dibandingkan antar siklus. Data yang dianalisis meliputi data yang terkumpul dari hasil pengamatan yang berasal dari format aktivitas siswa dan guru dalam menggunakan model lacak kata. Data yang dianalisis berbentuk angka,diperoleh dari hasil uji kompetensi penggunaan lacak kata yang dijawab oleh siswa pada akhir setiap siklus.

Sesuai dengan metodologi penelitian tindakan kelas (PTK) penelitian dilaksanakan dalam tiga siklus, masing-masing siklus terdiri dari 4 tahap, yaitu 1) perencanaan, 2) pelaksanaan, 3) pengamatan, dan 4) pemantulan. Berikut ini dijelaskan hasil yang diharapkan dari siklus penelitian dan tahapan penelitian.

\section{HASIL PENELITIAN DAN PEMBAHASAN}

\section{Hasil Penelitian}

Hasil siklus I diperoleh rata-rata kelas 77,4 , nilai tertinggi 90 dan nilai terendah 56. Rentangan nilai tertinggi 100 dan terendah 0 . Siswa yang belum tuntas 16 orang dari 36 orang siswa atau $44,4 \%$ sedang yang sudah tuntas 20 orang atau $55,6 \%$.

Pada siklus II,diperoleh nilai rata-rata kelas 85,3 nilai tertinggi 92 dan terendah 75. Siswa yang belum tuntas 8 orang $(22,2 \%)$ sedang yang sudah tuntas sebanyak 28 orang $(77,8 \%)$. Siklus II telah menunjukkan hasil yang lebih baik darisiklus I.

Pada siklus III,diperoleh nilai rata-rata kelas 88,4, nilai tertinggi 95 dan terendah 78. Siswa yang belum tuntas 5 orang 13,9\% sedang yang sudah tuntas sebanyak 31 orang atau $86,1 \%$. Hasil ini menunjukkan hasil yang lebih berarti dibandingkan dengan siklus kedua. Setiap akhir siklus dianalisis dan dilakukan perenungan(refleksi). Hasil perenungan digunakan untuk memperbaiki siklus berikutnya.

\section{Penjelasan Per - Siklus}

\section{a. Siklus I}

\section{1). Perencanaan}

Kegiatan yang dilakukan sesuai tahap perencanaan adalah: a). Rencana Pelaksanaan Pembelajaran(RPP),b). Lembaran Kegiatan Peserta Didik(LKPD), c). Pembagian Kelompok, d). Panduan Observasi, d). Panduan Penilaian dan e).Waktu atau jadwal pelaksanaan siklus 1

Kompetensi dasar yang yang dilaksanakan pada siklus 1, yaitu " KD. 3.11. Mengidentifikasi isi, struktur, dan kebahasaan teks negosiasi”. Kegiatan pembelajaran pada siklus1akan dilaksanakan dalam $3 x$ pertemuan. 


\section{2). Pelaksanaan}

Siklus I peneliti lakukan pada tanggal 9, 14 dan 21 Januari 2020. dengan materi “ Teks Negosiasi". Pelaksanaan sesuai dengan RPP yang telah direncanakan pada tahap sebelumnya.

\section{Pertemuan I}

Kegiatan pendahuluan, dilakukan sesuai kegiatan pra pembebelajaran yang meliputi: salam, berdoa, mengngondisikan siswa, appersepsi, motivasi, konsep tentang esensi materi, langkah, penilaian, dan pembagian kelompok selama 30 menit.

Kegiatan Inti, meliputi: 1) siswa membaca materi yang berkaitan dengan topik yang dibicarakan yaitu tentang teks negosiasi, 2) siswa duduk dalam kelompok, 3) guru membagikan LKPD (lampiran 3) yeng berisi langkah kegiatan yang harus dilakukan siswa dengan menggunakan model lacak kata, 4) siswa membaca dan memahami LKPD, 5) siswa mempertanyakan LKPD, 6) siswa mengisi LKPD sesuai dengan pemandu atau perintah. Saat berdiskusi siswa diberi kesempatan untuk membaca buku sumber agar mereka mempunyai dasar yang kuat untuk mengisi LKPD yang dikerjakan.

Kegiatan penutup, siswa mengumpulkan LKPD, guru memberikan simpulan, reflesi dan memberitahukan kegiatan untuk pertemuan berikutnya.

\section{Pertemuan II.}

Kegiatan pendahuluan,dilakukan sesuai kegiatan pra pembebelajaran yang berupa penguatan dari pertemuan sebelumnya yang meliputi: salam, berdoa, mengondisikan siswa, appersepsi, motivasi dan esensi materi,

Kegiatan Inti, 1). Siswa menyempurnakan tugas pada kegiatan sebelumnya, 2) Ketua kelompok mencabut lot untuk penentuan kelompok yang tampil untuk mempresentasikan tugas kelompok, 3) kelompok lain memberikan masukan, pertanyaan, penilaian dan saran.

Kegiatan penutup, 1) siswa menyimpulkan pembelajaran siklus 1,2) guru memberikan penegasan, 3) siswa mengemukakan refleksinya terhadap pembelajaran, 4) siswa mengumpulkan LKPD untuk diberi nilai oleh guru. 5) guru memberitahukan kegiatan untuk pertmuan berikutnya

\section{Pertemuan 3.}

Kegiatan pada pertemuan ke tiga yaitu tes atau uji kompetensi. Tes atau uji kompetensi diberikan pada setiap individu. Tes atau uji kompetensi dijadikan sebagi nilai akhir dari siklus I

\section{3). Observasi}

Observasi dilakukan bersamaan dengan tahap pelaksanaan tindakan oleh peneliti dengan menandai (chek list) tindakan yang dilakukan sesuai dengan format pengamatan yang telah disediakan. Format observasi yang disediakan meliputi lembar observasi RPP, lembar observasi aktivitas guru, lembaran observasi aktivitas siswa, lembar observasi hasil belajar siswa.

\section{4). Refleksi}

Kegiatan refleksi pada siklus I antara lain:

a).Refleksi RPP

Berdasarkan hasil pengamatan terhadap RPP yang dilakukan pada siklus I KD

"Mengidentifikasi isi, struktur dan kebahasaan teks negosiasi" tidak ditemukan kelemahan. Guru telah membuat RPP sesuai dengan model yang digunakan.

b). Refleksi terhadap aktivitas guru 
Berdasarkan hasil pengamatan terhadap aktivitas guru. Guru telah melaksanakan kegiatan dalam RPP sesuai dengan rencana yang telah dibuat.

c). Refleksi terhadap aktivitas siswa

Berdasarkan hasil pengamatan terhadap aktivitas siswa, siswa tidak pasif menerima materi, tetapi mereka mulai mengembangkan nalar,bertanya, antusias Namun, masih ditemukan kelemahan terutama ketika berdiskusi untuk mengerjakan format 1 , dan 2 . Pada langkah ini, kebanyakan siswa yang aktif bekerja hanya 2 orang tiap kelompok. Dua orang lagi tidak aktif dan kurang bertanggung jawab. Jika ditanya, mereka menjawab bahwa mereka sudah ikut diskusi.

d). Refleksi terhadap hasil belajar

Berdasarkan hasil pengamatan terhadap hasil belajar siklus pertama belum begitu bagus, masih berada di bawah KKM yakni nilai 77 .

\section{b.Siklus II}

\section{1). Perencanaan}

Berdasarkan hasil perenungan, maka diputuskan kegiatan pembelajaran masih tetap seperti siklus I. Namun, teknis pembelajaran dirubah. Jika pada siklus I, teknis pelaksanaannya secara berkelompok, pada siklus II teknisnya dirubah yaitu siswa bekerja secara mandiri.

\section{2). Pelaksanaan}

\section{Pertemuan I}

Kegiatan pendahuluan, dilakukan sesuai kegiatan pra pembebelajaran yang meliputi: salam, berdoa, mengngondisikan siswa, appersepsi, motivasi dan esensi materi,

Kegiatan Inti, meliputi: 1) siswa membaca materi yang berkaitan dengan topik yang dibicarakan yaitu tentang teks Debat, 2) siswa duduk di kursinya masing-masing, 3) guru membagikan LKPD yang berisi langkah kegiatan yang harus dilakukan siswa dengan menggunakan model lacak kata, 4) siswa membaca dan memahami LKPD, 5) siswa mempertanyakan LKPD, 6) siswa mengisi LKPD sesuai dengan perintah. (Sebelum bekerja siswa diberi kesempatan untuk membaca buku sumber agar mereka mempunyai dasar yang kuat untuk mengisi LKPD yang dikerjakan)

Kegiatan penutup, siswa mengumpulkan LKPD, guru memberikan simpulan, reflesi dan memberitahukan kegiatan untuk pertemuan berikutnya.

\section{Pertemuan II.}

Kegiatan pendahuluan, dilakukan sesuai kegiatan pra pembebelajaran yang meliputi: salam, berdoa, mengondisikan siswa, appersepsi, motivasi, serta esensi materi, Kegiatan Inti, meliputi: 1) guru kembali membagikan LKPD, 2) siswadiberi waktu 15 menit menyempurnakan tugas yang belum selesai, 3) salah seorang siswa diambil secara acak untuk tampil mempresentasikan tugas pribadinya, 4) siswa lain memberikan masukan, pertanyaan, penilaian dan saran.

Kegiatan penutup, 1) siswa menyimpulkan pembelajaran siklus II) guru memberikan penegasan, 3) siswa mengemukakan refleksinya terhadap pembelajaran, 4) masing-masing siswa mengumpulkan LKPD untuk diberi nilai oleh guru. 5) guru memberitahukan kegiatan untuk pertemuan berikutnya yaitu tes siklus 2 


\section{Pertemuan III.}

Kegiatan pada pertemuan ke tiga yang dilakukan yaitu tes atau uji kompetensi. Siswa secara pribadi mengerjakan tes yang disediakan. Kemudian lembaran jawaban dikumpulkan untuk diberi penilaian sebagai hasil Siklus II.

\section{3). Observasi}

Observasi dilakukan bersamaan dengan tahap pelaksanaan tindakan dengan menandai (chek list) tindakan yang dilakukan sesuai dengan format pengamatan yang telah disediaka, lembaran pengamatan aktivitas siswa, lembar pengamatan hasil belajar siswa.

a) Aspek pengamatan RPP

Berdasarkan pengamatan terhadap RPP, nilai skor yang diperoleh pada hasil penilaian RPP untuk KD. "Mengidentifikasi isi, struktur dan kebahasaan teks Debat"

b) Aspek pengamatan aktivitas guru

Berdasarkan hasil pengamatan terhadap aktivitas guru dalam kegiatn pembelajaran siklus II adalah 90. Hal ini menunjukkan bahwa kriteria keberhasilan guru termasuk kualifikasi B (Baik). .

c).Aspek pengamatan aktivitas siswa

Berdasarkan hasil pengamatan yang dilakukan terhadap aktivitas siswa dalam kegiatan pembelajaran siklus II, siswa aktif dan antusias serta bertanggung jawab dengan tugas masing-masing.

d). Aspek pengamatan hasil belajar siswa

Pengamatan aspek pengetahuan dilihat dari lembar evaluasi yang dilakukan pada akhir pembelajaran. Nilai tertinggi yang diperoleh pada aspek pengetahuan 92 dan terendah 75 . Jumlah nilai 3071. Rata-rata nilai pengetahuan 85 , 3. Siswa yang tuntas 28 orang(77,8\%), Siswa yang tidak tuntas 8 orang $(22,2 \%)$. Hal ini menunjukkan bahawa keberhasilan belajar siswa pada aspek pengetahuan rata-ratanya sudah di atas KKM.

\section{4).Refleksi}

Kegiatan refleksi pada siklus II sebagai berikut:

a). Refleksi terhadap RPP

Berdasarkan hasil pengamatan terhadap RPP yang dilakukan pada siklus II KD "Mengidentifikasi isi, struktur dan kebahasaan teks Debat" tidak ditemukan kelemahan. Guru telah membuat RPP sesuai dengan model yang digunakan.

b). Refleksi terhadap aktivitas guru

Berdasarkan hasil pengamatan terhadap aktivitas guru tidak ditemukan kelemahan. Guru telah melaksanakan kegiatan dalam RPP sesuai dengan rencana yang telah dibuat.

c). Refleksi terhadap aktivitas siswa

Berdasarkan hasil pengamatan terhadap aktivitas siswa, siswa aktif menerima materi, mereka mulai mengembangkan nalar,bertanya, antusias yang ditunjukkan tidak mau minta izin keluar, mereka mencatat materi di belakang lacak kata yang dibagikan. Materi dipahami oleh siswa tanpa banyak diterangkan, karena sudah terdapat dalam lacak kata dalam bentuk pertanyaan mendatar dan menurun.

d). Refleksi terhadap hasil belajar

Berdasarkan hasil pengamatan terhadap hasil belajar siklus ke dua sudah bagus, dengan nilai 85 berada di atas KKM .

Berpijak pada temuan di atas maka dapat disimpulkan bahwa keberhasilan pencapaian tujuan pembelajaran yang diharapkan dengan menggunakan mode lacak kata belum maksimal. Belum terjadi peningkatan yang signifikan dalam pembelajaran dengan 
menggunakan model lacak kata. Hasil pemantulan ini dapat dijadikan sebagai perbaikan. Hal-hal yang belum terlaksana dapat direalisasikan pada siklus III.

Untuk itu, penelitian perlu dilanjutkan ke siklus III dengan memperbaiki kelemahan pada siklus II.

\section{c. Siklus III}

Siklus ke tigadihatapkan lebih baik dari siklus ke dua. Bagian yang belum optimal dapat direalisasikan sesuai perencanaan yang telah dirancang.Pada siklus ke tiga sesuai dengan prosedur PTK terdiri dari data perencanaan, pelaksanaan,pengamatan dan pemantulan.

\section{1). Perencanaan}

Kegiatan pembelajaran masih tetap seperti siklus II. Namun, pembelajaran lebih dikembangkan. Berpijak pada reflesi siklus II, terlihat semua siswa terlibat secara aktif. Maka pada siklus III tinggal pengembangan. Teknisnya masih tetap sama dengan siklus II yaitu secara pribadi. Masing- masing siswa tetap bertanggung jawab dengan tugasnya, karena nilai diambil secara pribadi. Siswa tetap dipandu dengan LKPD. Namun LKPD dikembangkan. Siswa tidak hanya sekedar mencari jawaban mendatar dan menurun, tetapi siswa juga menuliskan apa yang diketahuinya tentang kata mendatar dan menurun. Siswa diberi tugas sebelum pembelajaran untuk mebaca materi yang akan dipelajari.

\section{2). Pelaksanaan}

\section{Pertemuan I}

Kegiatan pendahuluan, dilakukan sesuai kegiatan pra pembebelajaran yang meliputi: salam, berdoa, mengngondisikan siswa, appersepsi, motivasidan esensi materi

Kegiatan Inti, meliputi: 1) siswa membaca materi sepintas yang berkaitan dengan topik yang dibicarakan yaitu tentang teks Biografi, 2) siswa duduk di kursinya masing-masing, 3) guru membagikan LKPD (lampiran 17) yang berisi langkah kegiatan yang harus dilakukan siswa dengan menggunakan model lacak kata, 4) siswa membaca dan memahami LKPD, 5) siswa mempertanyakan LKPD, 6) siswa mengisi LKPD sesuai dengan perintah. Sebelum bekerja(pertemuan sebelumnya) siswa diminta untuk membaca buku sumber terkait materi agar mereka mempunyai wawasan dan dasar yang kuat untuk mengisi LKPD yang dikerjakan.

Kegiatan penutup, siswa mengumpulkan LKPD, guru memberikan simpulan, refleksi dan memberitahukan kegiatan untuk pertmuan berikutnya.

\section{Pertemuan II.}

Kegiatan pendahuluan, dilakukan sesuai kegiatan pra pembebelajaran yang meliputi: salam, berdoa, mengondisikan siswa, appersepsi, motivasi dan esensi materi.Kegiatan Inti, meliputi: 1) siswa menyempurnakan tugas yang belum selesai, 2) salah seorang siswa dipilih sicara acak diminta tampil untuk mempresentasikan tugas pribadinya, 3) siswa lain memberikan masukan, pertanyaan, penilaian dan saran. Kegiatan penutup, 1) siswa menyimpulkan pembelajaran siklus II) guru memberikan penegasan, 3) siswa mengemukakan refleksinya terhadap pembelajaran, 4) siswa mengumpulkan LKPD untuk diberi nilai oleh guru. 5) guru memberitahukan kegiatan untuk pertemuan berikutnya yaitu tes siklus 3

\section{Pertemuan III}

Kegiatan pada pertemuan ke tiga yang dilakukan yaitu tes atau uji kompetensi. Siswa secara pribadi mengerjakan tes yang disediakan. Sebelum jam berakhir, lembaran jawan tes dikumpulkan untuk diberikan penilaian sebagai hasil akhir siklus III. 


\section{3). Observasi}

Observasi dilakukan bersamaan dengan tahap pelaksanaan tindakan oleh pengamat dengan menandai (chek list) tindakan yang dilakukan sesuai dengan format pengamatan yang telah disediakan. Format observasi yang disediakan meliputi lembar pengamatan RPP, lembar pengamatan aktivitas guru, lembaran aktivitas siswa, lembar pengamatan hasil belajar siswa.

a). Aspek pengamatan RPP

Berdasarkan pengamatan terhadap RPP, nilai skor yang diperoleh pada hasil penilaian RPP untuk KD. "Mengidentifikasi isi, struktur dan kebahasaan teks Biografi" siklus III yaitu 93 dengan kualifikasi Baik.

b). Aspek pengamatan aktivitas guru

Berdasarkan hasil pengamatan yang dilakukan terhadap aktivitas guru dalam kegiatn pembelajaran siklus III adalah 91. Hal ini menunjukkan bahwa kriteria keberhasilan guru termasuk kualifikasi B.

c). Aspek pengamatan aktivitas siswa

Berdasarkan hasil pengamatan yang dilakukan observer terhadap aktivitas siswa, siswa semakin antusias karena sudah paham dengan apa yang dikerjakan. Hasil pengamatan terhadap aktivitas siswa dalam kegiatan pembelajaran siklus III adalah 88. Hal ini menunjukkan bahwa kriteria keberhasilan siswa termasuk kualifikasi B(Baik).

d). Aspek pengamatan hasil belajar siswa

Pengamatan aspek pengetahuan dilihat dari lembar evaluasi yang dilakukan pada akhir pembelajaran siklus III. Nilai tertinggi yang diperoleh pada aspek pengetahuan 95 dan terendah 78. Jumlah nilai siswa 3181 . Rata-rata nilai pengetahuan 88,4 . Siswa yang tuntas 31 orang $(86,1 \%)$, siswa yang tidak tuntas 5 orang $(13,9 \%)$. Hal ini menunjukkan bahwa keberhasilan belajar siswa pada aspek pengetahuan sudah jauh di atas KKM.

\section{4). Refleksi}

Kegiatan refleksi pada siklus III sebagai berikut:

a).Refleksi RPP

Berdasarkan hasil pengamatan terhadap RPP yang dilakukan pada siklus III KD "Mengidentifikasi isi, struktur dan kebahasaan teks Biografi" tidak ditemukan kelemahan. Guru telah membuat RPP sesuai dengan model yang digunakan.

b). Refleksi terhadap aktivitas guru

Berdasarkan hasil pengamatan terhadap aktivitas guru tidak ditemukan kelemahan. Guru telah melaksanakan kegiatan dalam RPP sesuai dengan rencana yang telah dibuat.

c). Refleksi terhadap aktivitas siswa

Berdasarkan hasil pengamatan terhadap aktivitas siswa, siswa lebih aktif dalam mengikuti pembelajaran karena disamping bertanggung jawab dengan tugas pribadinya, siswa paham dengan apa yang akan dikerjakannya. Mereka mengembangkan nalar, tidak lagi bertanya, bersemangat dan lebih cepat menyiapkan tugasnya., karena keasikkan mengisi kata-kata yang mendatar, menurun, dan menjelaskan konsep kata atau istilah yang diisikan.

d). Refleksi terhadap hasil belajar

Berdasarkan hasil pengamatan terhadap hasil belajar siklus ke tiga sudah sangat bagus, dengan nilai rata-rata 88,4 berada di atas KKM .

Dari temuan di atas maka dapat disimpulkan bahwa keberhasilan pencapaian tujuan pembelajaran yang diharapkan dengan menggunakan model lacak kata sudah maksimal. Sudah terjadi peningkatan yang signifikan dalam pembelajaran. Hasil pemantulan ini dapat 
dijadikan sebagai dasar pengambilan keputusan bahwa penelitian tidak perlu dilanjutkan ke siklus berikutnya.

\section{Pembahasan}

Berdasarkan hasil analisis data penelitian siklus I, II, dan III dapat dilihat bahwa telah terjadi peningkatan hasil belajar siswa dan antusias siswa yang signifikan dalam mengikuti pembelajaran. Berikut ini akan dibahas masing-masing aspek yang diteliti:

Pembahasan hasil tes siswa mengacu pada peningkatan hasil belajar siklus I, II, dan III sebagaimana tergambar pada diagram 1 berikut:

\section{Diagram 1. \\ Perbandingan Nilai Tes Siswa Siklus I, II, dan III}

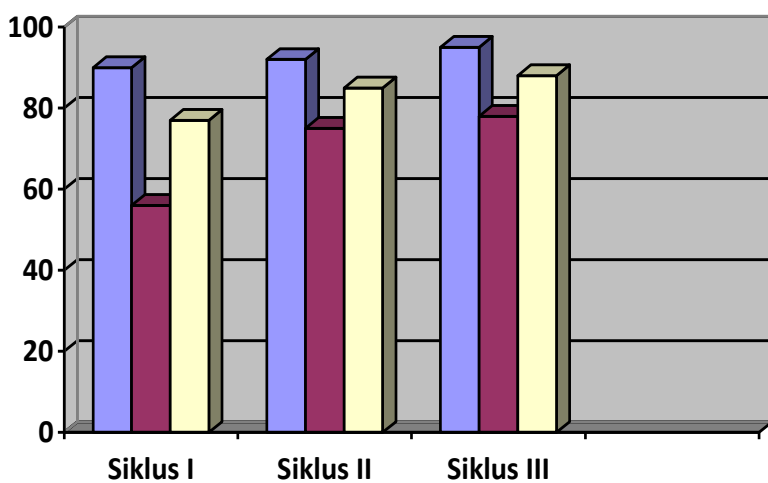

Di samping itu, persentase nilai ketuntasan siswa juga meningkat setiap siklus. Diahram 1 di atas mengindikasikan telah terjadinya peningkatan ketuntasan nilai siswa setiap siklus. Hal ini berbanding terbalik dengan menurunnya siswa yang tidak tuntas setiap siklus.

Untuk melihat perbandingan nilai ketuntasan siswa siklus I, II, dan III dapat dilihat pada diagram 2 berikut:

Diagram 2.

\section{Perbandingan Persentase Nilai Ketuntasan Siswa Siklus I, II dan III}

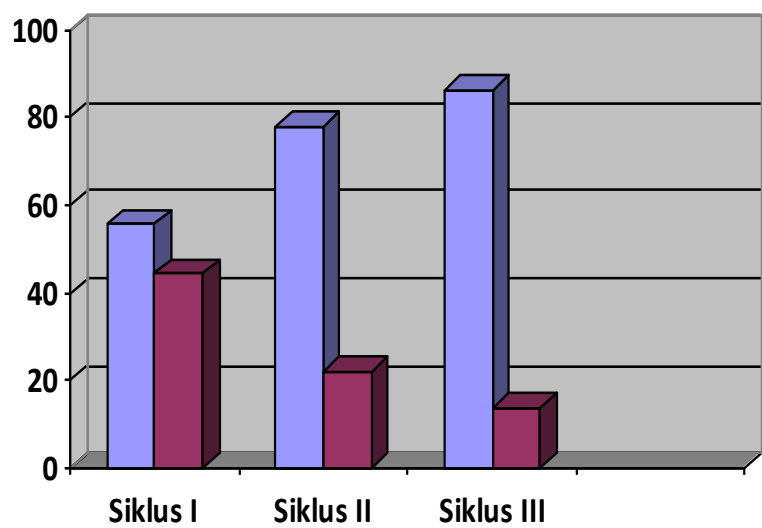

Digram 2 di atas mengungkapkan bahwa nilai A untuk aktivitas dan sikap siswa meningkat setiap siklus. Kontradiksi dari peningkatan nilai A, maka nilai $\mathrm{B}$ dan $\mathrm{C}$ mengalami 
penurunan setiap siklus. Hal ini dapat disimpulkan bahwa telah terjadi peningkatan aktivitas dan sikap siswa pada setiap siklus.

Hasil analisis pengamatan terhadap aktivitas dan sikap siswa tergambar pada diagram 3 berikut:

\section{Diagram 3}

\section{Perbandingan Persentase Aktivitas dan Sikap Siswa}

Siklus I,II, dan III
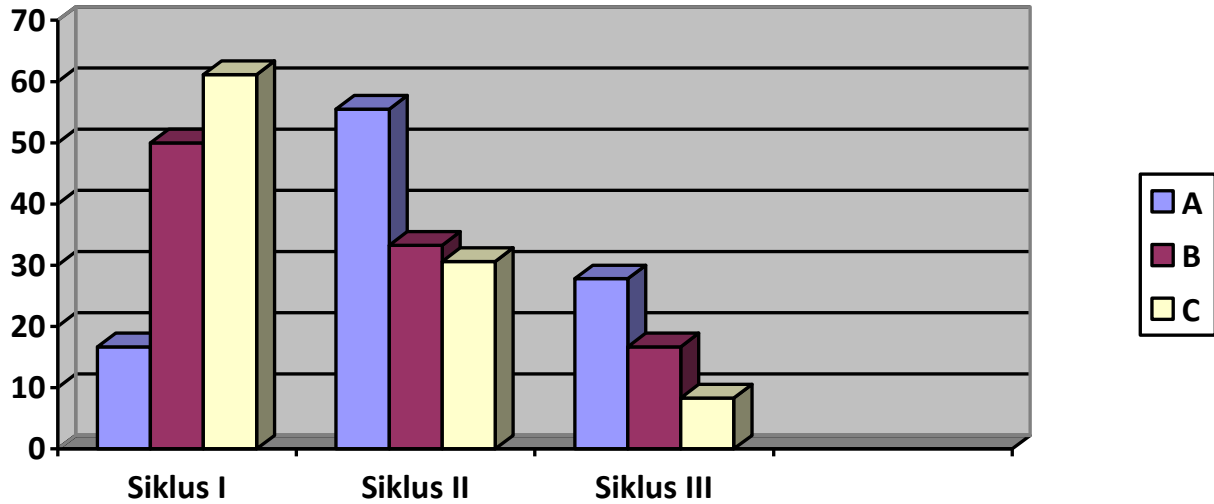

Di samping itu, untuk melihat peningkatan aktivitas dan sikap siswa per aspek yang dinilai dapat dinilai pada tabel 1 berikut:

Tabel 1

Peningkatan Aktivitas dan Sikap Siswa

Siklus I, II, dan III Per Aspek yang Diamati

\begin{tabular}{|l|l|c|c|c|c|c|c|c|c|c|}
\hline No & Aspek yang & \multicolumn{9}{c|}{ \% Rata-rata } \\
\cline { 3 - 12 } & \multirow{2}{*}{ Diamati } & \multicolumn{3}{|c|}{ Siklus I } & \multicolumn{3}{c|}{ Siklus II } & \multicolumn{3}{c|}{ Siklus III } \\
\cline { 3 - 12 } & & A & B & C & A & B & C & A & B & C \\
\hline 1. & Kesungguhan & 38,9 & 33,3 & 27,8 & 50 & 38,8 & 11,1 & 61,1 & 27,8 & 11,1 \\
\hline 2. & Keaktivan & 25 & 50 & 25 & 41,7 & 44,4 & 13,9 & 58,3 & 30,6 & 11,1 \\
\hline 3. & Ketepatan & 13,9 & 72.2 & 13,9 & 55,6 & 27,8 & 16,7 & 72,2 & 19,4 & 8,3 \\
\hline
\end{tabular}

Tabel 1 di atas menggambarkan bahwa telah terjadi peningkatan aktivitas dan sikap siswa per aspek yang diamati setiap siklus. Peningkatan persentase nilai A setiap siklus membuat nilai $\mathrm{B}$ dan $\mathrm{C}$ menurun setiap siklus. Hal ini membuktikan bahwa peningkatan aktivitas dan sikap siswa per aspek yang diamati meningkat setiap siklus.

Hasil analisis perbandingan aktivitas dan sikap siswa peraspek yang diamati dapat dilihat pada diagram 4 berikut:

\section{Diagram 4.}

Perbandingan Persentase Aktivitas dan Sikap Siswa per Aspek yang Diamati

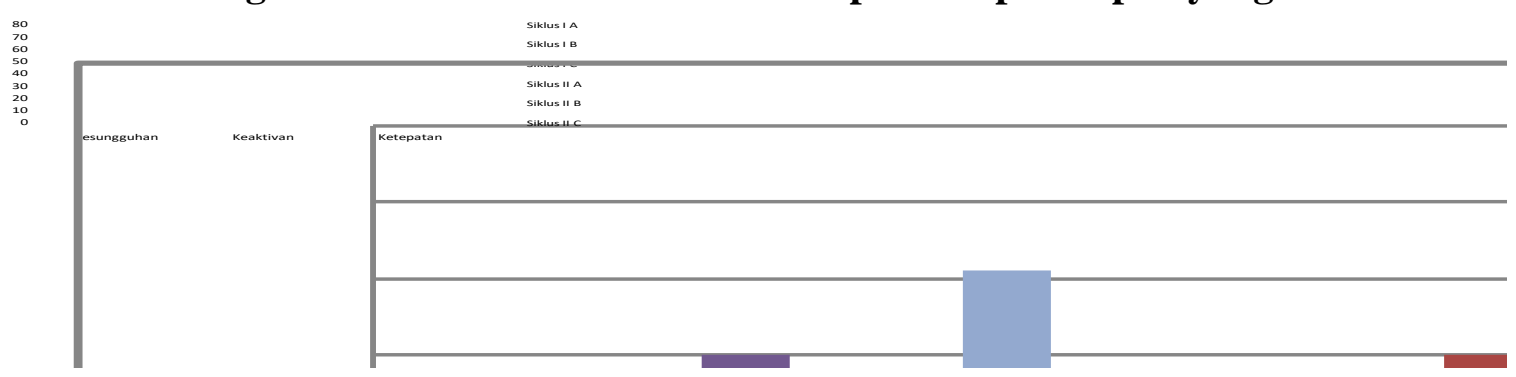


Kemampuan guru dalam melaksanakan PBMakan mempengaruhi peningkatan prilaku siswa dalam menerima pelajaran.Hasil analisis terhadap perbandingan aktivitas guru dapat dilihat pada diagram berikut:

\section{Diagram 5. \\ Perbandingan Persentase \\ Aktivitas Guru dalam Pelaksanaan PBM Siklus I, II, dan III}

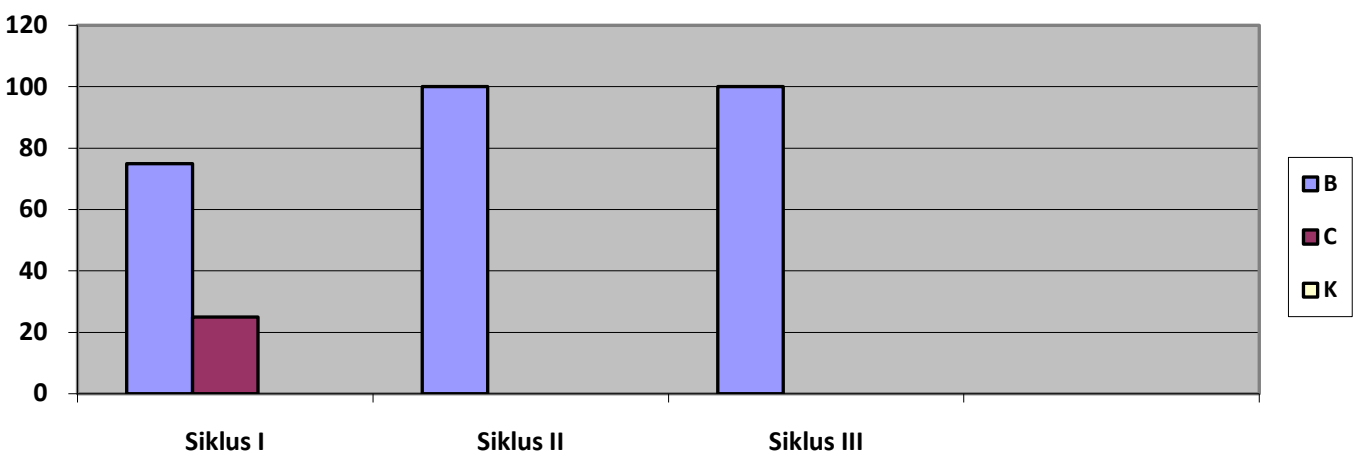

Berdasarkan hasil tes dan non tes di atas dapat disimpulkan bahwa telah terjadi peningkatan yang signifikan dan tajam terhadap hasil belajar siswa dengan menggunakan model pembelajaran Lacak Kata. Hasil penelitian ini mendukung penelitian yang dilakukan oleh Risda 2003 yang meneliti tentang "Studi Perbandingan antara Pembelajaran Siswa dengan Pemberian Tugas dalam Bentuk Cross Word ( TTS) dan Bentuk Pertanyaan Biasa pada Penguasaan Konsep Metabolisme Sel di SMA Negeri 1 Batusangkar.“ Hasil penelitiannya menunjukkan terjadinya peningkatan hasil belajar siswa pada materi metabolisme yang diberi tugas dengan metode latihan coss word ( TTS) dan dengan latihan bentuk pertanyaan biasa pada kelas III IPA.1 SMA Negeri 1 Batusangkar.

Di samping itu juga mendukung penelitian yang dilakukan oleh Soewoto(2000) yang mengatakan bahwa proses komunikasi harus diciptakan melalui kegiatan penyampaian dan tukar menukar informasi oleh guru dan siswa. Gurulah yang tahu situasi dan kondisi siswa di kelas. Tugas guru tidak hanya menuangkan sejumlah informasi kebenak siswa, tetapi mengusahakan agar konsep-konsep penting dan berguna tertanam kuat dalam ingatan siswa. Guru harus pandai menentukan tindakan dan memilih metode dan model yang tepat untuk mencapai hasil yang diharapkan. Kecocokan antara metode, model dengan materi akan menghasilkan pembelajaran yang bermakna dan menyenangkan.

Dalam penelitian ini, peneliti telah menyiapkan model lacak kata dengan mempedomani kurikulum yang berlaku yaitu kurikulum 2013. Pertanyaan dibuat dengan bentuk mendatar dan menurun.

Semua pertanyaan baik mendatar maupun menurun telah disiapkan kunci jawaban terlebih dahulu. Soal sesuai dengan silabus dan RPP. Peneliti mengambil keputusan penilaian berdasarkan petunjuk penilaian yang berlaku.

Siswa yang mendapat nilai 80 ke bawah berarti harus mengikuti program remedial (perbaikan), karena KKM (Kriteria Ketuntasan Minimal) untuk KD ini adalah 80. Bagi siswa yang mendapat nilai di atas 80 berarti sudah tuntas dan mendapat pendalaman materi yang relevan dengan materi yang telah disajikan. 


\section{E.PENUTUP}

\section{Kesimpulan}

Berdasarkan hasil dan pembahasan data penelitian, maka dapat disimpulkan hal-hal sebagai berikut :

a. Terdapatnya peningkatanmotivasi siswa dalam belajar melalui penggunaan model lacak kata.Siswa terbiasa membaca sehingga budaya literasi meningkat, karena dengan membaca mereka tahu dan wawasannya berkembang. Akibatnya, siswa bersemangat mengisi lacak kata pada LKPD yang diberikan. Dengan berminatnya siswa mengikuti pelajaran, kegiatan literasi yang biasanya menjenuhkan berangsur-angsur hilang dalam kehidupan siswa. Siswa akan menganggap membaca itu adalah suatu kebutuhan.

b. Penggunaan model lacak kata perlu disiapkan dengan baik. siswa bukan hanya asal mengacak kata saja, tetapi mereka juga bisa bernalar dan mengembangkan konsep ilmu yang didapatkannya.

c. lacak kata membuat siswa seolah-olah bermain, tetapi sebenarnya mereka mengasah otak untuk menempatkan kata yang tepat pada kolom yang disediakan, sehingga sangat berpengaruh dalam meningkatkan kreativitas siswa dalam mengerjakan tugas baik pribadi maupun kelompok.

\section{Saran}

Berdasarkan hasil penelitian tindakan kelas di atas dapat diajukan saran antara lain:

a. Agar guru dapat menggunakan model lacak kata sebagai salah satu inovasi yang bisa meningkatkan aktifitas siswa untuk belajar.

b. Penggunaan model lacak katadapat mengatasi kesulitan dalam belajar mengajar, di mana siswa yang tidak mempunyai buku dan catatan akan terbantu dengan model lacak kata.

c. Guru perlu menciptakan situasi dan kondisi yang kondusif agar siswa mengisi lacak kata lebih teliti dan siap. Dengan penerapan model ini akan diperoleh hasil yang memuaskan..

d. Agar penerapan model ini dapat berjalan dengan baik, diperlukan persiapan yang matang dan terencana dengan baik.

\section{F. DAFTAR PUSTAKA}

Hamalik, Oemar. 2005. Metode Belajar dan Kesulitan-kesulitan Belajar. Edisi III Bandung: Tarsito

2009. Pendidikan Guru Berdasarkan Pendekatan Kompetensi. Bandung: Bumi Aksara

Hidayah, Nur. 2013. Panduan Praktis Penyusunan Pelaporan Penelitian Tindakan Kelas. Jakarta: Prestasi Pustaka

Hopkins, David. 1993. A. Teacher Guide to Classroom Research. Philadelpia: Open University Press

Kesuma, Ameliasari T .2013. Menyusun PTK itu Gampang. Jakarta : Essensi Erlangga Group

Margono.2004. Metodologi Penelitian Pendidikan. Jakarta: Rineka Cipta

Permendikbud No.22 Tahun 2016 tentang Standar Proses Pendidikan Dasar dan Menengah Permendikbud No.23 Tahun 2016 tentang Standar Penilaian Pendidikan Dasar dan Menengah

Permendikbud No.24 Tahun 2016 tentang Kompetensi Inti dan Kompetensi Dasar Kurikulum 2013 
Risda.2003. Studi Perbandingan antara Pembelajaran Siswa dengan Pemberian Tugas dalam Bentuk Cross Word ( TTS) dan Bentuk Pertanyaan Biasa pada Penguasaan Konsep Metabolisme Sel. ( Laporan Hasil Penelitian)

Semiawan, Cony. 2000. Psikologi Anak dan Remaja. Bandung: Remaja Rosdakarya Slameto. 2015. Belajar dan Faktor-faktor yang Mempengaruhinya. Jakarta : Rineka Cipta Silberman, Melvin L. 2005Active Learning ( 101 Cara Belajar Siswa akrif) . Terjemahan: Raisul Muttaqien . Bandung: Nusamedia

Soewoto. 2000. Laporan akhir Penelitian Tindakan Kelas:Penggunaan Media Gambar Transparan untuk Meningkatkan Pemahaman Siswa Kelas III IPA SMA Negeri 7 Malang

Stix, Andi dan Hrbek Frank.2007. Guru Sebagai Pelatih Kelas. Jakarta: Erlangga

Sujanto, Agus. 2012. Psikologi Perkembangan. Jakarta: Bumi Aksara

Suryabrata. Sumadi. 2000. Metodologi Penelitian. Jakarta: Rajawali Pers

Trisupeni. 1994. Paket Inservis Tinjau Kurikulum. Jakarta: Depdiknas

Guntur Tarigan, Hendri. 2011. Pengajaran Kosakata. Bandung: Angkasa

Winkel.W.S..1999. Psikologi Pengajaran. Jakarta: Grasindo 